Luis Eduardo Cobra Lacorte

Rodolfo Andrade Gouveia Vilela ${ }^{2}$

Reginalice da Cera Silva ${ }^{3}$

Anna Maria Chiesa ${ }^{4}$

Elisa Sartori Tulio ${ }^{5}$

Robson Ramalho Franco ${ }^{6}$

Ecléa Spiridião Bravo ${ }^{7}$

\section{Os nós da rede para erradicação do trabalho infanto- -juvenil na produção de joias e bijuterias em Limeira - SP}

\author{
The knots of the child labor eradication network within the \\ jewelry and costume jewelry production in Limeira, \\ São Paulo, Brazil
}

${ }^{1}$ Programa de Saúde do Trabalhador. Serviço de Vigilância Sanitária. Secretaria Municipal de Saúde de Limeira. Limeira, SP, Brasil.

${ }^{2}$ Deartamento de Saúde Ambiental da Faculdade de Saúde Pública da Universidade de São Paulo. São Paulo, SP, Brasil. ${ }^{3}$ Faculdade de Saúde da Universidade Metodista de Piracicaba. Piracicaba, SP, Brasil.

${ }^{4}$ Departamento de Enfermagem em Saúde Coletiva da Escola de Enfermagem da USP. São Paulo, SP, Brasil.

${ }^{5}$ Bolsista Fapesp Treinamento Técnico Nível III (Processo Fapesp n⿳ำ 2010/17687-0). São Paulo, SP, Brasil.

${ }^{6}$ Sindicato dos Empregados em Estabelecimentos Bancários e Financeiros de Limeira. Limeira, SP, Brasil.

${ }^{7}$ Centro de Referência em Saúde do Trabalhador de Piracicaba. Secretaria Municipal de Saúde de Piracicaba. Piracicaba, SP, Brasil.

Contato:

Luis Eduardo Cobra Lacorte

E-mail:

pitepira@gmail.com

Trabalho baseado na dissertação de mestrado de Luis Eduardo Cobra Lacorte intitulada A construção de políticas públicas em rede intersetorial para a erradicação do trabalho infantil em Limeira-SP, defendida em 2012 na Faculdade de Saúde Pública da Universidade de São Paulo.

O estudo recebeu o apoio da Fundação de Amparo à Pesquisa do Estado de São Paulo (Fapesp), processo n⿳ำ 17.896/2010.

Os autores declaram não haver conflitos de interesse.

Recebido: 02/03/2012

Revisado: 16/08/2013

Aprovado: 20/08/2013

\section{Resumo}

Introdução: A cidade de Limeira, em São Paulo, abriga o maior polo de produção de joias e bijuterias do país caracterizado pela terceirização, destacando-se a exploração de trabalho infantil, em condições de nocividade para a saúde do trabalhador. Para enfrentar este problema, articulou-se uma rede intersetorial. Objetivo: descrever as ações da rede e destacar limites e potencialidades de seu processo de formação e consolidação. Métodos: realizou-se estudo de caso, combinando a análise documental e a participação direta dos pesquisadores nas atividades no período de 2007 a 2011. Resultados: analisaram-se aspectos culturais, ideológicos e institucionais que determinavam a situação e as ações que propiciaram mudanças. Coube destaque à construção do Termo de Ajustamento de Conduta, que assegurou a implantação de ações coordenadas, a realização de diversos eventos de sensibilização, a mobilização da população, a implantação do Programa de Saúde do Trabalhador e a criação de grupos de trabalho que discutem a temática constantemente com a finalidade de articular a rede intersetorial. Conclusão: a governança em rede propicia o estabelecimento de um processo de transformação cultural e institucional para o enfrentamento do trabalho infantil. É imprescindível realizar novas intervenções neste fluxo produtivo de modo a implicar o empresariado em um processo de mudança.

Palavras-chaves: trabalho infantil; política pública; promoção da saúde; produção de joias e bijuterias.

\section{Abstract}

Introduction: The city of Limeira, in the state of São Paulo, Brazil, is the largest cluster of companies producing jewelry and costume jewelry in the country. It features outsourcing and child labor exploitation, bringing harm to workers' health. To address this problem an Inter-sectorial Network was organized. Objective: Describe actions and highlight the limits and potentialities of the Network building and consolidation processes. Methods: The authors conducted a case study, combining documental analysis, and researchers' direct participation in the activities carried out between 2007 and 2011. Results: They analyzed the cultural, ideological and institutional aspects that determined the situation as well as the actions that produced changes. An important action was the settlement of an agreement called "Termo de Ajustamento de Conduta" (Conduct Adjusting Terms), which ensured implementing the coordinated actions and the Occupational Health Program, organizing events to raise awareness and mobilize the population, as well as working groups with permanent discussions aiming at articulating the Network. Conclusion: The Network has encouraged an ongoing process of cultural and institutional transformation to deal with child labor. However, it is crucial that new contributions are offered to involve the entrepreneurs in this process of change.

Keywords: child labor; public policy; health promotion; jewelry and costume jewelry production. 


\section{Apresentação}

O fenômeno do Trabalho Infantil (TI) e do Trabalho Adolescente (TA) é uma realidade social expressa em diferentes culturas e sociedades na história da humanidade e caracteriza-se por envolver crianças e adolescentes, sobretudo de classes sociais desprivilegiadas, no sistema produtivo (THOMPSON, 1987).

O processo sócio-histórico da infância foi investigado por Campos e Alverga (2001), os quais desvelaram as linhas discursivas que fundamentaram "a ideologia do trabalho como educador". A ética cristã dos países ibéricos e a moral puritana, hegemônica na Inglaterra no século XVIII, foram apontadas como as bases para a "dignificação pelo trabalho", evocando uma fé cega no trabalho a despeito das condições em que este era exercido. Ao analisar o desenvolvimento econômico na Inglaterra, durante a Revolução Industrial, os autores evidenciaram que o TI e/ou o TA fizeram parte do êxito econômico obtido pelos países que implantavam a industrialização.

A concepção ideológica da sociedade ocidental legitimava a exploração do TI por meio de um discurso que atribuía ao trabalho caráter protetor e disciplinador e direcionava crianças pobres para o trabalho como forma de prevenir o envolvimento com o crime e a marginalidade. $\mathrm{O}$ espaço fabril era concebido em oposição ao espaço da rua, caótico e desregulado. Ademais, para as famílias que viviam na miséria, qualquer incremento na renda familiar era vital, contribuindo para a inserção das crianças no espaço produtivo (THOMPSON, 1987; ALVIM, 1994 apud MINAYO-GOMEZ; MEIRELLES, 1997). Nessa conjuntura, a inserção no trabalho tornou-se política pública para os órfãos empregados como "aprendizes" em funções penosas, seja nas indústrias têxteis ou na limpeza de chaminés (THOMPSON, 1987).

As linhas discursivas que fundamentaram tais políticas, no contexto da Revolução Industrial, passaram por algumas sofisticações e se perpetuam até o presente, dificultando a consolidação de cultu- ra afirmativa dos direitos à infância (THOMPSON, 1987; VILANI, 2007). O reconhecimento dessa realidade ocorre gradualmente, a partir do momento em que a sociedade ocidental começa a perceber a infância como fase peculiar de desenvolvimento humano e que necessita de cuidados específicos. O livro A história social da criança e da família (ARIÈS, 1981) possibilita vislumbrar longa trajetória cultural da emergência do sentimento de infância (Renascimento Cultural, Revolução Industrial, Iluminismo) e a sua influência no pensamento científico moderno. Essa questão tem ocupado espaço na agenda política mundial, sobretudo após o advento da Declaração Universal dos Direitos da Criança (UNITED NATIONS, 1959).

No Brasil, o TI é reconhecido como um problema de saúde pública que demanda políticas públicas de diferentes setores (MINAYO-GOMEZ; MEIRELLES, 1997; NOBRE, 2003; ASMUS et al., 2005; NOVOTNY et al., 2009). Seu enfrentamento avançou a partir da Constituição Federal de 1988 e, principalmente, após a publicação do Estatuto da Criança e do Adolescente - ECA (BRASIL, 1990). Ambos os documentos proíbem expressamente o TI, com ressalvas ao adolescente após os 14 anos, na condição de aprendiz e em trabalho que não apresente riscos.

O ECA (BRASIL, 1990) foi um marco que possibilitou o avanço de ações diversificadas na promoção da saúde das crianças e dos adolescentes e viabilizou mudanças significativas para as formas de proteção legal destinadas a esta população. Seus desdobramentos potencializaram a intersetorialidade e estão em consonância com as diretrizes e as práticas dos setores saúde, educação, trabalho, desenvolvimento social, bem como dos poderes legislativo e judiciário (BRASIL, 2005a, 2005b). Contudo, apesar de uma legislação considerada avançada em relação a outros países (VILANI, 2007; SCHWARTZMAN, 2001), e do Brasil registrar avanços na última década em comparação à década de 1990, os números do trabalho infantil no país ainda são expressivos, como mostra a Tabela 1.

Tabela 1 Evolução do número de crianças e adolescentes envolvidos em trabalho infantil no Brasil

\begin{tabular}{lllllllllll}
\hline \multicolumn{1}{c}{ Ano } & 1992 & 1995 & 1998 & 2001 & 2003 & 2004 & 2005 & 2007 & 2009 & 2011 \\
\hline $\begin{array}{l}\text { Número absoluto de } \\
\text { trabalhadores de } \\
\begin{array}{l}\text { a a 17 anos } \\
\text { (em milhões) }\end{array}\end{array}$ & 8,4 & 8,2 & 7,7 & 5,4 & 5,1 & 5,3 & 5,5 & 4,8 & 4,5 & 4,2 \\
\hline
\end{tabular}

Fonte: Lacorte (2012, p. 7) 
Importante esclarecer que essas crianças e adolescentes estão expostos às complexas situações de vulnerabilidade social e têm seus direitos sociais negligenciados ou negados. Um dos efeitos perversos dessa realidade refere-se ao trabalho infantil que comporta risco e exposição aos ambientes de trabalho insalubres que comprometem seu desenvolvimento biopsicossocial.

Apesar dos avanços alcançados no século XX, as transformações que vêm ocorrendo na organização do trabalho compõem um quadro de reestruturação produtiva e de movimentos de mundialização da economia desfavorável aos trabalhadores. Este movimento se manifesta de diversas formas: flexibilização dos vínculos; precarização das relações de trabalho; e terceirizações de atividades-fim que são ilegais no Brasil, possibilitando às empresas maior competitividade e rentabilidade em detrimento da saúde e do bem-estar dos trabalhadores, expondo-os a situações de risco e tornando-os vulneráveis (CASTEL, 1998; ALVES, 2000; ANTUNES, 2007).

Os esforços para a Erradicação do Trabalho Infantil (ETI) e a garantia do trabalho seguro aos adolescentes maiores de 14 anos aumentaram na década de 1990, marcados pela inclusão do Brasil no International Programme on the Elimination of Child Labour (IPEC) da Organização Internacional do Trabalho (CENTRO INTEGRADO DE ESTUDOS E PROGRAMAS DE DESENVOLVIMENTO SOCIAL, 2006; FERREIRA, 2001).

Em 1994, foi criado o Fórum Nacional de Prevenção e Erradicação do Trabalho Infantil (Fnpeti), sob a coordenação do Ministério do Trabalho, com o apoio do Fundo das Nações Unidas para a Infância (Unicef) e participação de ONGs, empresários, sindicalistas, igreja, poder legislativo e judiciário (CARVALHO, 2004).

Enquanto estratégia não governamental de articulação, mobilização e sensibilização da sociedade, o Fnpeti consolidou um espaço democrático de discussão do tema, responsável pelo acompanhamento da implantação das metas do Plano Nacional de Prevenção e Erradicação do Trabalho Infantil e de Proteção ao Trabalhador Adolescente (BRASIL, 2004).

As políticas atuais do setor Saúde trazem em suas concepções a noção de que o problema é de extrema complexidade, tendo suas origens nas relações econômicas, trabalhistas, sociais, culturais e políticas que determinam e condicionam o estado de saúde das populações (MINAYO-GOMEZ; MEIRELES, 1997; FERREIRA, 2001; NOBRE, 2003; ASMUS et al., 2005; VILELA; FERREIRA, 2008).

Este fenômeno se expressa de diferentes formas no Brasil. A região sudeste, apresenta um avançado desenvolvimento econômico e registra o menor nível
$(7,9 \%)$ de trabalhadores entre cinco e dezessete anos (INSTITUTO BRASILEIRO DE GEOGRAFIA E ESTATÍSTICA, 2009). No entanto, existem focos de trabalho infantil em cidades com importante expressão econômica no Estado de São Paulo. O município de Limeira-SP, por exemplo, com população de 274.000 habitantes, abriga o maior polo de produção de joias e bijuterias do país, sendo responsável por $60 \%$ da produção. Em 2006, o setor faturou cerca de US\$ 220 milhões, dos quais US\$132 milhões somente em Limeira (TONOCCHI, 2006). Conhecido como a capital do folheado, o Arranjo Produtivo Local (APL) é caracterizado pela terceirização, pela informalidade, pela exploração do TI e pelo trabalho em condições improvisadas nos domicílios, configurando-se como exemplo de nocividade para a saúde dos trabalhadores (FERREIRA, 1995).

O processo produtivo pode ser resumido em sete etapas: criação, estampagem, montagem, banho, cravação, soldagem e expedição.

Foi constatado por Vilela e Ferreira (2008) que principalmente a montagem, a cravação, a soldagem e até mesmo o banho são terceirizados para famílias que realizam a produção em suas moradias. Nesse processo, o fluxo de produção do setor engendra empresas formais e famílias carentes por meio de "atravessadores" e estabelecem, dessa maneira, uma relação de interdependência entre as etapas produtivas formais e informais.

Duas questões surgem neste fluxo produtivo. A primeira é o envolvimento de crianças e adolescentes, principalmente nas atividades de montagem, soldagem e cravação de peças. Foi constatado na pesquisa de Ferreira (1995) que 8.340 alunos da rede estadual (27\%) desenvolviam, no setor, tarefas repetitivas e perigosas, expostos a riscos biomecânicos, químicos e a acidente de trabalho. Os riscos à saúde são agravados pelo sistema de remuneração dos trabalhadores terceirizados (incluindo as crianças e os adolescentes), que ganham por produção. A cada mil peças montadas, o trabalhador recebia naquele período do estudo cerca de $R \$ 3,00$ a $R \$ 5,00$ e um trabalhador montava em média de três a quatro mil peças por dia, o que lhe conferia uma renda diária em torno de $\mathrm{R} \$ 9,00$ a $\mathrm{R} \$ 20,00$. Na atividade de soldagem, os números mudavam para uma produção que variava de uma e meia a duas mil peças, sendo pago entre $R \$ 10,00$ a $R \$ 25,00$ por milheiro, o que garantia rendimento de $\mathrm{R} \$ 25,00$ a $\mathrm{R} \$ 30,00$ ao dia (VILELA; FERREIRA, 2008). O pagamento por produção intensifica o trabalho e acentua os riscos de lesão (MAENO et al., 2001).

A segunda questão é de âmbito ambiental, amplamente discutida na pesquisa de Ferreira (1995), a qual constatou que metais pesados e outros produtos 
perigosos, oriundos dos banhos de galvanoplastia da produção de joias e bijuterias, eram despejados na rede de esgoto residencial sem tratamento, contaminando os rios e os canais que atravessam o município de Limeira. As amostras indicaram uma concentração de Cobre $(\mathrm{Cu}) 117$ vezes acima dos níveis comumente encontrados em rede de esgoto do tipo domiciliar (amostra controle) e 325 vezes maior de Zinco (Zn). Além desses, também foram encontradas concentrações de Níquel (Ni), Ouro (Au) Cromo $(\mathrm{Cr})$ e Chumbo $(\mathrm{Pb})$.

O diagnóstico da situação teve forte repercussão quando publicado no jornal O Estado de São Paulo no dia 12 de dezembro de 2006 com o título Produção de Joias de Limeira emprega 6 mil crianças e jovens (TONOCCHI, 2006). A notícia cita o estudo realizado por Ferreira (1995) e aponta alguns números da pesquisa: $62,1 \%$ dos adolescentes entrevistados afirmam realizar trabalhos repetitivos, $32 \%$ sentem dores nas mãos e nos braços, $42 \%$ sentem dores em ombros, pescoço e coluna, dados que compõem o quadro de saúde pública do município.

Um dos impactos sentidos diretamente pelos empresários foi o bloqueio de recursos do Banco Nacional de Desenvolvimento Econômico e Social (BNDES). Segundo verbalização do representante da Associação Limeirense de Joias (Aljoias), durante a primeira reunião de retomada da criação da Cometil, a divulgação da pesquisa pela imprensa ao tornar públicos os aspectos sociais e ambientais do setor teria provocado o bloqueio de financiamento na ordem de 20 milhões de reais, que já teria sido aprovado para o Arranjo Produtivo Local (APL).

Em função da repercussão e do impacto da pesquisa, em 2007 as entidades representativas do empresariado do setor comprometeram-se a realizar um seminário objetivando discutir soluções para os desafios trabalhistas e ambientais identificados. O representante do Sindicato da Indústria de Joalheria, Bijuteria e Lapidação de Gemas do Estado de São Paulo (Sindijoias) declarou, nas reuniões iniciais da comissão, que essa iniciativa visava envolver todos os setores da cadeia produtiva, órgãos de fiscalização, imprensa e especialistas. Afirmou ainda que a principal preocupação das associações e dos sindicatos do setor era combater as empresas clandestinas que desestabilizavam o mercado devido à competição desleal.

Apesar do discurso do segmento empresarial, durante o seguimento da pesquisa empírica, que acompanhou as reuniões intersetoriais no período de 2007 a 2011, não foram observadas, pelos pesquisadores, práticas de combate à informalidade nem a realização do prometido seminário. Contudo, em 2007, foi mobilizada, pelo poder público e pela sociedade civil organizada, uma Comissão Intersetorial para o enfrentamento dessa situação em consonância com a Portaria no 458 (BRASIL, 2001).

O presente artigo visa reconstituir e analisar o histórico de ações dessa Comissão para compreender os limites e as potencialidades do processo de construção e consolidação de uma rede intersetorial cujos objetivos eram: erradicação do trabalho infantil; proteção do trabalho adolescente; garantia da proteção integral da criança e do adolescente; e readequação do fluxo produtivo do setor de joias e bijuterias de modo a eliminar a terceirização domiciliar.

\section{Abordagem metodológica}

Realizou-se um estudo de caso, de abordagem qualitativa, que combinou a análise documental e a participação direta dos pesquisadores nas atividades desenvolvidas. Essa abordagem é utilizada em pesquisas nas áreas sociais, políticas, com técnicas diversas. Propõe uma estrutura para coleta de dados, triangulação e análise de dados sob a luz de um determinado referencial teórico resultando em uma análise aprofundada do caso (YIN, 2002).

A análise documental resgatou as atas de reuniões da instância organizadora das ações intersetoriais elaboradas no período de 2007 a 2011 e três arquivos audiovisuais de eventos relevantes que ocorreram na Câmara dos Vereadores, os quais foram transcritos e analisados. Também foram levantadas as inserções na mídia escrita (jornais do município de Limeira - Gazeta de Limeira e Jornal de Limeira dentre o recorte temporal 2007 - 2010) que foram submetidas a uma análise sistemática, de modo a auxiliar na reconstrução do histórico da Comissão Municipal.

Os pesquisadores (três autores deste artigo) também acompanharam as reuniões e as ações desenvolvidas pela Comissão nos anos de 2007 a 2011 por meio de pesquisa-ação que integrou o projeto de mestrado intitulado A Construção de Políticas Públicas em Rede Intersetorial para a Erradicação do Trabalho Infantil em Limeira-SP (LACORTE, 2012). O mestrando participava das reuniões também representando o Cerest de Piracicaba. Outro integrante coordenava o grupo na qualidade de controle social e foi convidado a refletir na elaboração deste texto. O terceiro autor participou das reuniões na qualidade de pesquisador bolsista de treinamento técnico nível III por meio de financiamento de projeto fapesp (processo 2010/ 17687-0). O projeto foi aprovado pelo Comitê de Ética em Pesquisa da Faculdade de Saúde Pública da USP (Protocolo COEP 2211).

A pesquisa-ação é pertinente para investigar o produto da interação dos atores implicados na mu- 
dança, capaz de promover a organização social para a intervenção, posto que a problemática teórica e metodológica inscreve-se em uma "totalidade sociológica” em constante transformação (THIOLLENT, 2000; COULON, 1992).

Segundo Thiollent (2000), a pesquisa-ação tem como princípios fundamentais: forte interação entre pesquisadores, atores e membros das situações investigadas; negociação e consenso sobre os objetivos; participação ativa dos interessados (com ciclos de ação/ reflexão/ação); levantamento de dados e interpretação, com procedimentos coletivos (grupos, seminários, oficinas, redes etc.); devolução da informação aos interessados; proposição de ações viáveis com avaliação de resultados; e, por fim, sistematização do conhecimento obtido. A pesquisa-ação está relacionada a projetos emancipatórios e autogestionários que almejam mudança na realidade concreta com participação social efetiva (ROCHA; AGUIAR, 2003). No caso deste artigo, o objeto de estudo trata-se de uma comissão intersetorial que envolve diferentes instituições.

Para reconstituir e analisar a história da instituição da Comissão Intersetorial, os autores recorreram aos referenciais da Promoção da Saúde (BRASIL, 2002), com destaque para os conceitos e as práticas da Educação Permanente em Saúde (CECCIM, 2004, 2005) e Governança em Rede (KAMP; NIELSEN, 2009).

Educação Permanente em Saúde é o processo educativo que valoriza o cotidiano do trabalho, atravessado pelas relações concretas vivenciadas pelos servidores, e que possibilita construir espaços coletivos para a reflexão e a avaliação de sentidos dos atos produzidos diariamente.

A Educação Permanente em Saúde insere-se em uma necessária construção de relações e processos que vão do interior das equipes em atuação conjunta, implicando seus agentes - às práticas organizacionais, - implicando a instituição e/ou o setor da saúde - e às práticas interinstitucionais e/ou intersetoriais, - implicando as políticas nas quais se inscrevem os atos de saúde. (CECCIM, 2004, p. 161)

Para Kamp e Nielsen (2009), a governança em rede pode ser compreendida como a inter-relação, estável ou periódica, entre instituições que são operacionalmente autônomas, que interagem ou precisam interagir por meio de negociações, com a finalidade de potencializar suas ações, que se autorregulam dentro dos escopos de suas atuações, contribuindo para um governo estabelecido em âmbito coletivo, originando novos entendimentos para o processo de formulação de políticas. As redes são compreendidas como instituições assinaladas por valores, concepções, normas que são construídas a partir da contribuição de cada integrante e das interações estabelecidas (KAMP; NIELSEN, 2009).

Os conceitos apresentados corroboram com a intenção dos autores deste estudo de refletir sobre as estratégias utilizadas, enfocando o processo de transformação cultural iniciado por meio das ações da referida Comissão, salientando os principais avanços e descrevendo os instrumentos que os concretizaram.

\section{Resultados e discussão}

Foram analisadas 39 atas da Cometil, 3 arquivos audiovisuais, sessenta e 65 artigos de jornais e 14 inserções na mídia televisiva que permitiram construir uma linha do tempo, apresentada na Figura 1, que representa o período principal de mobilização para a articulação de rede intersetorial.

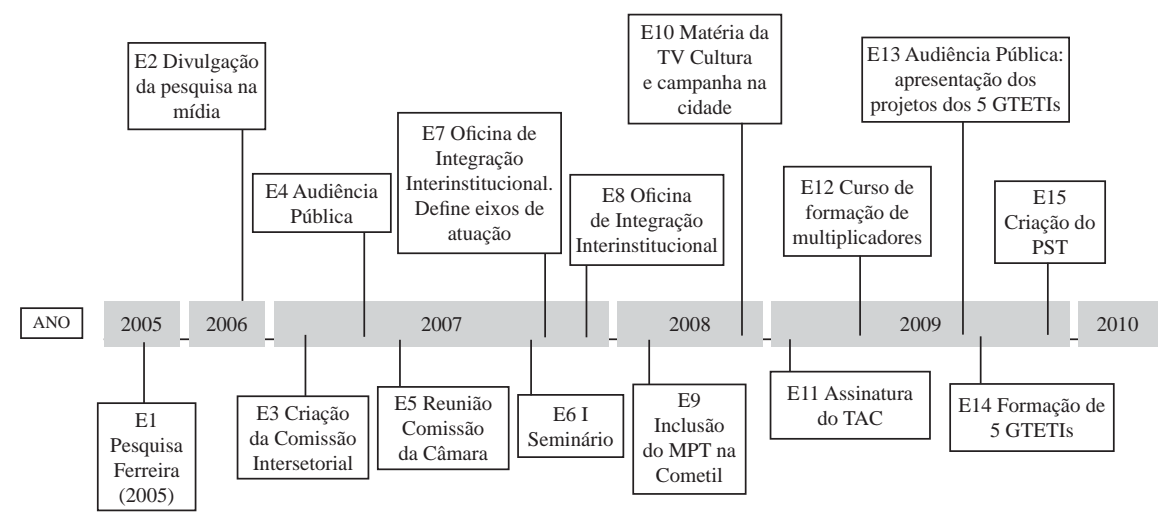

Siglas: GTETIs - Grupos Territoriais de Erradicação do Trabalho Infantil MPT - Ministério Público do Trabalho

PST - Programa Saúde do Trabalhador

TAC - Termo de Ajustamento de Conduta

Figura 1 Linha do tempo dos eventos (E) marcantes da história da Comissão Municipal de Erradicação do Trabalho Infantil (Cometil) de Limeira, 2005-2010

Fonte: Lacorte (2012, p. 84) 
Os eventos E1 e E2 foram comentados na introdução deste artigo. A seguir, com base na análise documental, na participação e na observação direta dos pesquisadores, serão apresentados os eventos que fazem parte do contexto de articulação que culminou na criação e consolidação da rede intersetorial de ETI no município de Limeira.

\section{E3 - Contexto de criação da Comissão Intersetorial com Controle Social}

No início de 2007, o poder público, pressionado pelo Sindicato dos Empregados em Estabelecimentos Bancários e Financeiros de Limeira e com apoio do Fórum Estadual Paulista de Prevenção e Erradicação do Trabalho Infantil e do Centro de Referência em Saúde do Trabalhador de Piracicaba (Cerest), iniciou processo de articulação intersetorial e construção de uma rede de proteção integral à criança e ao adolescente por meio da reestruturação da Comissão do Programa de Erradicação do Trabalho Infantil (Peti) existente no município desde 2003.

O Sindicato dos Bancários teve participação ativa em diversas instâncias de controle social nas áreas de saúde, educação, desenvolvimento social, além de trabalho e renda, desempenhando papel preponderante no acompanhamento das políticas públicas executadas no município. Seus representantes afirmavam que a comissão existente anteriormente cumpria apenas o papel de gerenciar os recursos provenientes do Governo Federal sem ter, contudo, representatividade intersetorial, como é recomendado na Portaria no 458, (BRASIL, 2001) e sua complementar Portaria no 666 (BRASIL, 2005c).

Inicialmente foram mobilizados os quatro setores entendidos como os principais para a transformação da realidade local, a saber: Saúde, Educação, Desenvolvimento Social, Trabalho e Renda. Também foram incluídas as entidades representantes do setor produtivo, a Associação Limeirense de Joias (ALJ), o Sindijoias e o Sindicato dos Trabalhadores das Indústrias de Joalheria e Lapidação de Pedras Preciosas e Bijuterias (Sintrajoias). Também foram incluídas as entidades que representam o controle social: Conselho Tutelar, Conselho Municipal dos Direitos da Criança e do Adolescente (CMDCA), Conselho Municipal de Assistência Social (CMAS), Conselho Municipal de Educação (CME), Conselho Municipal de Saúde (CMS). Nesse formato reestruturado, esse coletivo passou a ser conhecido como a Comissão Municipal de Erradicação do Trabalho Infantil de Limeira (Cometil).
Levando em conta esse cenário e atuando sob a perspectiva da vigilância em saúde, que visa intervir nos determinantes e condicionantes da saúde das populações, essa rede intersetorial tinha como meta implementar políticas públicas capazes de garantir:

- a erradicação do trabalho infantil;

- a proteção do trabalho adolescente;

- a proteção integral da criança e do adolescente; e

- a readequação do fluxo produtivo do setor de joias e bijuterias de modo a eliminar a terceirização domiciliar.

Os autores sistematizaram essas metas com base nas atas analisadas, Embora essas metas não estivessem organizadas dessa forma em nenhum documento oficial, essa proposta de sistematização foi validada com os participantes do grupo ${ }^{8}$.

\section{E4 - Audiência pública}

A 1a Audiência Pública foi realizada na Câmara Municipal de Limeira no dia 12 de junho de 2007 com intuito de mobilizar e articular os munícipes frente à questão do trabalho infantil, promovendo reflexão e garantindo espaço para o debate (COMISSÃO MUNICIPAL DE ERRADICAÇÃO DO TRABALHO INFANTIL, 2007a).

Na ocasião, compareceram à Câmara de Vereadores aproximadamente 70 participantes, entre eles:

- gestores dos setores da Saúde, Educação e Desenvolvimento Social do município de Limeira;

- representantes de universidades da região;

- representante do Ministério Público do Trabalho - Procuradoria Regional do Trabalho da 15a Região (MPT); e

- representantes do Cerest Piracicaba.

Foram realizadas três apresentações: a primeira mostrou a pesquisa realizada no município (FERREIRA, 1995); em seguida, o Centro de Promoção Social Municipal (Ceprosom), autarquia que desenvolve as políticas públicas da Secretaria Municipal de Desenvolvimento Social e executa o serviço de atendimento à criança e ao adolescente, expôs os programas executados para a identificação da situação de TI e os atendimentos realizados.

Vale destacar que um dos projetos apresentados pelo Ceprosom- "Jovens Brilhantes" - destinava-se à preparação para inserção desta população no merca-

${ }^{8}$ Essas metas foram sistematizadas no protocolo de intenções que veio a ser firmado no evento 6 - O “I Seminário Municipal para Erradicação do Trabalho Infantil - Diagnóstico e Alternativas". 
do de trabalho. O programa era viabilizado por meio de parceria com a Associação Limeirense de Joias e apoio do sindicato patronal do setor. Nesse projeto, jovens com menos de 16 anos aprendiam técnicas de montagem e soldagem de peças, atividades perigosas que não poderiam ser desenvolvidas por menores de 18 anos, segundo o ECA (1990).

Apesar da pesquisa de Ferreira (1995) apontar mais de 8.300 crianças/adolescentes em situação de risco, o Ceprosom apresentou dados fornecidos pelo setor Saúde do município que indicavam apenas duas Comunicações de Acidente de Trabalho (CAT) envolvendo menores de 18 anos. Apesar da reconhecida subnotificação dos Acidentes de Trabalho (AT) no Brasil, o número reduzido de CAT foi utilizado pelo órgão público como argumento para se contrapor à realidade trazida pela pesquisa.

A terceira apresentação, realizada por Procuradora do Ministério Público do Trabalho (MPT), abordou os mitos sobre o TI e apresentou dados científico-acadêmicos do campo da saúde e da pedagogia de modo a oferecer subsídios para desconstruir a ideologia do trabalho como educador.

O debate ocorrido após a apresentação da Procuradora mostrou as diferentes visões acerca do TI, possibilitou que representantes da sociedade civil mostrassem evidências do problema, tais como baixo rendimento escolar dos adolescentes trabalhadores, agentes públicos despreparados para reconhecer sua magnitude, subnotificação de doenças e acidentes, dentre outros, além de questionar as autoridades presentes quanto às medidas para enfrentamento do problema.

Duas reflexões merecem destaque. A primeira, enunciada por um conselheiro tutelar, de que o TI e TA constituíam um problema complexo que demandava o envolvimento das três secretarias ali representadas - Saúde, Educação e Ceprosom - para desenvolver um trabalho intersetorial. A segunda, compartilhada por um vereador, que Limeira apresenta alta concentração de renda e, apesar da legislação vigente, o TI ainda era defendido por alguns vereadores e gestores do município como alternativa para os menos abastados, perpetuando a ideologia do trabalho formador/ protetor (CAMPOS; ALVERGA, 2001).

Manifestando sua discordância e sustentando o mito da "dignificação pelo trabalho" a Secretária de Saúde afirmou:

\footnotetext{
Se Limeira tem pessoas abastadas, eu reconheço porque tenho setenta e dois anos e conheço muitas pessoas que são abastadas hoje em dia, é porque trabalharam muito, desde criança. [...] Se o trabalho de ontem construiu as coisas de hoje, é porque realmente ficaram cientes da sua força, da personalidade, da sua dignidade. (LIMEIRA [MUNICIPIO], 2007b)
}

A Secretária de Saúde ao manifestar e reforçar a crença de que "o trabalho dignifica o homem", apresentou justificativas para a situação vivenciada em Limeira, de forma a banalizar a situação de TI.

Respondendo à indagação sobre o despreparo do Setor Saúde para identificar a magnitude do problema, a gestora, revelando também sua adesão ao modelo biomédico vigente, alegou que os médicos são concursados, possuem o diploma de graduação e estão, portanto, aptos a exercer a medicina. Tal afirmação desconsidera: o social como determinante dos problemas de saúde, que se restringiriam a uma questão "médica", e o papel de dirigente que deveria propor diretrizes e cobrar ações voltadas para proteger a saúde e qualidade de vida das crianças e dos adolescentes do município.

Seria necessário construir o entendimento de que o TI e/ou TA desprotegido se caracteriza como um sério problema de saúde pública naquele município.

\section{E5 - Reunião da Comissão de Assuntos Relevantes da Câmara Municipal de Limeira}

Para enfrentar as barreiras mencionadas anteriormente, o tema da ETI foi incluído na pauta da Comissão de Assuntos Relevantes e Direitos Humanos da Câmara de Vereadores, a pedido de um parlamentar integrante da Cometil, para pactuar uma estratégia de intervenção articulada com o Poder Público.

Em reunião ocorrida no dia 21 de junho de 2007, na presença do Secretário de Educação e da Secretária da Saúde, pela primeira vez o Cerest Piracicaba pôde apresentar sua proposta de ação, construída junto com os integrantes da Cometil, que indicava amplo processo de sensibilização/capacitação dos profissionais da saúde, da educação e do desenvolvimento social, pautado na perspectiva da vigilância em saúde, com objetivo de compreender os determinantes e os condicionantes de saúde daquela população e os efeitos que o TI e o TA desprotegido poderiam ocasionar a curto, médio e longo prazos nesse grupo etário. Esperava-se que, após este processo, os profissionais dos diferentes setores envolvidos se tornassem agentes multiplicadores para atuar diretamente com a população, por meio de ações de promoção da saúde. A proposta focava ações que contribuíssem para o empoderamento, por meio do desenvolvimento de habilidades dos sujeitos - da comunidade ou do corpo técnico dos serviços públicos -, bem como para o fortalecimento de ações comunitárias de modo a ampliar a capacidade de intervenção sobre os determinantes do TI e dos agravos à saúde dos adolescentes trabalhadores (BRASIL, 2001).

A reunião foi marcada por uma série de desentendimentos. Os gestores ainda sustentavam críticas 
à pesquisa que havia sido apresentada (FERRERA, 2005) e informaram a intenção de realizar novo levantamento para obter "dados fidedignos" em relação à situação de TI e TA dos munícipes. Essa proposta foi questionada uma vez que, no escopo de ações em propositura, seria implantado um sistema de notificação de casos a partir da estrutura existente na rede de saúde em Limeira, o que possibilitaria o acompanhamento dos índices gerados.

A proposta de capacitação dos servidores foi rechaçada pelos secretários, que exigiam evidências do "despreparo dos profissionais". Além disso, a Secretária de Saúde de Limeira repudiou a Audiência Pública (E4) organizada pela Cometil, pois, na sua avaliação, o evento foi descaracterizado por pessoas que estavam presentes "para fazer política” e desviavam o assunto para outros problemas como, por exemplo, a desigualdade social. Evidenciou-se assim, uma visão limitada sobre o trabalho infantil ao desconsiderar os determinantes sociais dessa realidade.

Os técnicos do Cerest justificaram a necessidade das ações de promoção da saúde para formar multiplicadores, esclareceram que, a priori, não se tratava de um "despreparo dos profissionais", mas sim de uma lacuna na formação deles pelo fato da Saúde do Trabalhador ser um campo de atuação em desenvolvimento dentro da Saúde Coletiva. Nesse sentido, os Cerests cumprem o papel de suporte técnico e científico e uma de suas principais atribuições é irradiar o saber relativo ao processo saúde/doença/trabalho.

Ao final da reunião, apesar dos desentendimentos técnicos/políticos, a Secretária de Saúde colocou-se à disposição da Cometil e se comprometeu a agendar uma reunião com representantes da comissão e do Cerest Piracicaba para desenvolver um planejamento das ações. Contudo, a referida reunião, apesar da insistência dos técnicos do Cerest, não aconteceu.

\section{E6 - I Seminário e Assinatura do Protocolo de Intenções}

O I Seminário Municipal para Erradicação do Trabalho Infantil - Diagnóstico e Alternativas foi uma iniciativa promovida pelo Cerest Piracicaba com recursos da Rede Nacional de Atenção Integral à Saúde do Trabalhador (Renast) e organizado em parceria com a Cometil. O evento ocorreu no dia 24 de agosto de 2007 e contou com a presença de representantes de importantes instituições que tradicionalmente combatem o Trabalho Infantil, dentre elas Ministério Público do Trabalho (MPT), Ministério do Trabalho e Emprego (MTE), Ministério da Saúde (MS), representado pela Coordenadoria de Saúde do Trabalhador (Cosat), Ministério do Desenvolvimento Social e Combate à Fome (MDS), Organização Internacional do Trabalho (OIT), Conselho Nacional de
Erradicação do Trabalho Infantil (Conaeti), representantes do Cerest Estadual, da Diretoria Regional de Ensino, de professores universitários de notório saber sobre a ETI. O evento também contou com representantes do poder público local, dentre eles o prefeito de Limeira, entre outros. Contou ainda com um público de aproximadamente 400 participantes (LIMEIRA [MUNICÍPIO], 2007a; COMISSÃO MUNICIPAL DE ERRADICAÇÃO DO TRABALHO INFANTIL, 2007b).

Na ocasião, foi realizada ampla discussão com apresentações de cada uma das instituições supracitadas e as formas como atuam na ETI e proteção do TA. Os representantes da OIT e do Conaeti enfatizaram a importância do trabalho em rede.

O Diretor Regional de Ensino de Limeira revelou um dado que chocou os presentes, declarou que 11 estudantes da rede estavam com problemas para a obtenção de Carteira de Identidade, pois tinham perdido suas impressões digitais por manipularem produtos químicos que são utilizados no processo de solda fria. Esses produtos haviam corroído as digitais de mais de uma dezena de alunos. Esse dado teve forte repercussão na mídia local (TRABALHO... 2007).

O representante do MTE propôs a assinatura do Protocolo de Intenções pela Erradicação do Trabalho Infantil em Limeira e Região, o qual foi assinado pelas autoridades presentes e pelo prefeito de Limeira. Assim, o poder público assume publicamente a responsabilidade pela erradicação do trabalho infantil (COMISSÃO MUNICIPAL DE ERRADICAÇÃO DO TRABALHO INFANTIL, 2007b).

A representante do MS sugeriu para os membros da Cometil a construção de um projeto para a articulação de rede intersetorial de proteção e atenção integral à saúde das crianças e dos adolescentes por meio do protagonismo do setor da saúde, que firmaria convênio com o Fundo Nacional de Saúde (FNS) para financiar as ações necessárias à articulação da referida rede. O evento teve forte repercussão segundo a avaliação dos participantes da Cometil e consolidou cenário favorável para o desenvolvimento de políticas públicas (BRASIL, 2007).

\section{E7 - Oficina de integração interinstitucional para de- finição dos eixos de atuação da Cometil}

Para elaborar o projeto intersetorial e cumprir a proposta de submetê-lo ao FNS, foi realizada, no dia 24 de setembro de 2007, a Oficina de Integração Interinstitucional das Ações Públicas para a Erradicação do Trabalho Infantil no Município de Limeira, com financiamento do MTE e organização da equipe do Cerest Piracicaba e de representantes da Cometil. 
Por meio de metodologia participativa, foram definidos os objetivos norteadores e as medidas de intervenção que se subdividiam em quatro eixos de atuação: Saúde, Educação, Assistência Social e Setor Trabalho/Produtivo (COMISSÃO MUNICIPAL DE ERRADICAÇÃO DO TRABALHO INFANTIL, 2007c).

Essa oficina viabilizou um espaço de reflexão compartilhada entre os diferentes setores presentes que objetivaram a busca de alternativas sustentáveis que ultrapassassem as políticas compensatórias de transferência de renda e incidissem também no fluxograma produtivo do setor de joias e bijuterias, eliminando o trabalho domiciliar.
Os representantes do setor produtivo começavam a reconhecer as evidências que apontavam para a necessidade de mudanças no arranjo produtivo local como uma estratégia imprescindível para a ETI em Limeira.

As ações elaboradas nessa oficina foram sistematizadas segundo os eixos de atuação referidos e apresentadas no Quadro 1.

O projeto foi submetido ao FNS no dia 25 de outubro de 2007. Apesar do parecer favorável da área técnica, o projeto não foi financiado com a justificativa da ocorrência de corte de recursos destinados ao setor saúde.

Quadro 1 Propostas de ação para erradicação do trabalho infantil por eixos de atuação setorial

\begin{tabular}{|c|c|}
\hline $\begin{array}{l}\text { Setor proponente / } \\
\text { executor: }\end{array}$ & Descrição da proposta de ação \\
\hline Setor Saúde & $\begin{array}{l}\text { Implantação do sistema de notificação de agravos relacionados ao trabalho envolvendo crianças e/ou } \\
\text { adolescentes; } \\
\text { Criação do sistema de identificação de casos de situação de trabalho infantil e/ou trabalho adolescente } \\
\text { irregular (ou desprotegido) por meio dos atendimentos realizados na rede de saúde a menores de } 18 \\
\text { anos; } \\
\text { Formação de multiplicadores para erradicação do trabalho infantil; } \\
\text { Criação do Programa de Saúde do Trabalhador (PST). }\end{array}$ \\
\hline Setor Educação & $\begin{array}{l}\text { Criação do sistema de identificação de casos de trabalho infantil e/ou trabalho adolescente irregular (ou } \\
\text { desprotegido) por meio do contato dos professores com os alunos; } \\
\text { Formação de multiplicadores para erradicação do trabalho infantil; } \\
\text { Ações de educação/transformação cultural nas escolas e nas comunidades escolares. }\end{array}$ \\
\hline $\begin{array}{l}\text { Setor Assistência } \\
\text { Social }\end{array}$ & $\begin{array}{l}\text { Articulação intersetorial para distribuição de bolsa Peti e outros benefícios do sistema de transferência } \\
\text { de renda; } \\
\text { Inclusão de todos os casos identificados pelos outros setores em programas de transferência de renda e } \\
\text { desenvolvimento de potencialidades; } \\
\text { Formação de multiplicadores para erradicação do trabalho infantil; } \\
\text { Educação/transformação cultural por meio da atuação junto às famílias atendidas pelos programas } \\
\text { sociais e nas comunidades do entorno dos centros comunitários. }\end{array}$ \\
\hline $\begin{array}{l}\text { Setor Público do } \\
\text { Trabalho e Setor } \\
\text { Produtivo* }\end{array}$ & $\begin{array}{l}\text { Formação de multiplicadores entre os empresários que defendam a importância da formalização e da } \\
\text { erradicaça do trabalho infantil e do trabalho adolescente no setor; } \\
\text { Educação/transformação cultural e campanhas de formalização dentro do setor produtivo; } \\
\text { Apoio financeiro a campanhas de sensibilização da sociedade (Folder); } \\
\text { Busca por fontes de financiamento para modernização e formalização do fluxo produtivo do setor. }\end{array}$ \\
\hline
\end{tabular}

*Composto por Ministério do Trabalho e Emprego, Centro de Referencia em Saúde do Trabalhador e representantes do setor produtivo de joias.

Fonte: Lacôrte (2012, p. 100) 
E8 - Capacitação: núcleo de estudos de saúde do adolescente

A Cometil realizou capacitação voltada para seus integrantes e para os profissionais do setor saúde por meio da Oficina de Atenção Integral à Saúde da Criança e do Adolescente Economicamente Ativo, ocorrida nos dias 21 e 22 de novembro de 2007, com o apoio de representantes do Programa de Saúde do Trabalhador Adolescente (PSTA) do Núcleo de Estudos da Saúde do Adolescente (NESA) ligado à Universidade do Estado do Rio de Janeiro (UERJ). Nessa ocasião, foram discutidas as ações de vigilância à saúde definidas pela Portaria no 777 (BRASIL, 2004) com o intuito de facilitar as ações da Cometil, em especial do setor saúde, para a implantação de um sistema de notificação compulsória de agravos à saúde de crianças e adolescentes (NOVOTNY et al., 2009).

Ainda no âmbito da oficina e tendo por base as discussões anteriores, foi proposta a implantação de um sistema de notificação dos casos de trabalho infanto-juvenil.

\section{E9 - Inclusão do MPT na Cometil}

No início de 2008, o Cerest Piracicaba contatou o MPT da 15a a Região de Campinas solicitando sua participação nas reuniões da Cometil para viabilizar um Termo de Compromisso de Ajustamento de Conduta (TAC) com o município, de modo a assegurar a implantação do plano coletivo aprovado na Oficina de Integração (E7).

O TAC foi construído de maneira participativa, coordenado por procurador do MPT da 15a Região de Campinas, o qual garantiu o envolvimento dos profissionais dos três setores públicos municipais na elaboração das suas cláusulas. Infelizmente, as ações previstas para o setor Trabalho/Produtivo, formuladas na ocasião da oficina (E7), não foram incluídas no TAC.

\section{E10 - Matéria da TV Cultura e campanhas na cidade}

A rede de televisão Cultura veiculou uma matéria no Jornal da Cultura ${ }^{9}$ que adquiriu relevância, pois abordou de forma precisa a problemática e intensificou o debate sobre o TI em Limeira, auxiliando nas articulações realizadas no ano de 2008 e favorecendo inclusive o processo de construção do TAC que estava em fase de elaboração na ocasião da matéria. O material também serviu de apoio para as campanhas que foram realizadas ao longo do ano e reafirmou mais uma vez a importância de articulação com a mídia nas ações que visam a uma transformação cultural para a promoção da saúde e da proteção da vida.

Em paralelo à elaboração do TAC, ao longo de 2008 foi realizada uma campanha de ETI pela Cometil, tendo como apoio o setor produtivo. Os membros da Cometil elaboraram o conteúdo de um folder, entregue ao Sindijoias para que providenciasse a arte gráfica e a impressão de 2.000 exemplares. O material foi distribuído nas escolas, em centros comunitários e em dois atos públicos organizados pela Cometil nas datas de 12 de junho (dia Internacional do Combate ao Trabalho Infantil) e 12 de outubro (Dia das Crianças).

Ainda em 2008, foi realizada uma oficina de sensibilização que alcançou aproximadamente 200 crianças e adolescentes com idades entre 11 e 17 anos. As crianças foram mobilizadas pela rede de ensino municipal e os adolescentes pelo Ceprosom, contando com os jovens que participavam dos programas de desenvolvimento de habilidades e protagonismo juvenil. $\mathrm{O}$ evento também alcançou adolescentes de duas escolas estaduais.

A estratégia de envolver os reais afetados pelo assunto foi considerada exitosa, pois os adolescentes que participaram avaliaram positivamente a ação e rapidamente se apropriaram de um discurso favorável à defesa da infância.

\section{E11 - Assinatura do TAC}

A Assinatura do Termo de Ajustamento de Conduta - TAC 5537/2009 (BRASIL, 2009) com a Prefeitura de Limeira aconteceu no ano de 2009. O TAC, que continua em vigor, tem sido importante para garantir a continuidade da implantação das ações definidas pela Cometil. As ações estratégicas asseguradas foram: realização do curso de formação de multiplicadores, criação do Programa de Saúde do Trabalhador e implantação de um sistema de identificação e notificação de casos de crianças e adolescentes em situação de trabalho.

\section{E12 - Curso de formação de multiplicadores}

O Curso de Formação de Multiplicadores para a Erradicação do Trabalho Infantil sempre foi um anseio da Cometil, contudo, somente com a força do TAC foi possível desenvolvê-lo. O curso foi concebido pela equipe do Cerest Piracicaba em parceria com o Departamento de Enfermagem em Saúde Coletiva da Escola de Enfermagem da USP/SP. A estratégia delineada foi pautada nos conhecimentos disseminados pelo educador Paulo Freire (1998),

${ }^{9}$ Matéria exibida em 11 de abril de 2008. Reportagem realizada por Aldo Quiroga, especialista em jornalismo social. 
os quais valorizam os processos educacionais participativos, favorecem a promoção da saúde e, em especial, os eixos de desenvolvimento de habilidades e empoderamento dos atores sociais. O público alcançado foi de 213 servidores que atuam nos setores da educação (municipal e estadual), da saúde e da assistência social (ambos da esfera municipal).

Os técnicos do Cerest Piracicaba identificaram quatro demandas a serem abordadas ao longo do curso: (1) Desenvolver compreensão crítica sobre o TI capaz de desconstruir os mitos sobre esse fenômeno; (2) Desenvolver compreensão crítica sobre o trabalho e as relações sociais estabelecidas nesse âmbito; (3) Desenvolver compreensão crítica sobre a infância, pautada em referenciais da pediatria e da psicologia; e (4) Desenvolver abordagem instrumental para planejar e executar ações que favoreçam a ETI, o combate ao TA desprotegido e a cultura afirmativa da infância. A professora da EE/USP propôs utilização da ferramenta Showed (WALLERSTEIN; BERNSTEIN, 1998) para o desenvolvimento de exercício no qual os processos de escuta e de ação foram assegurados ${ }^{10}$.

As turmas foram distribuídas pela Cometil de acordo com uma divisão de territórios, visando a viabilizar o encontro entre servidores de diferentes setores e equipamentos públicos que atuassem no mesmo território e, dessa forma, potencializar parcerias. A programação foi estrategicamente incluída no TAC para garantir a realização do curso.

O curso foi realizado no período de 25 de março a 20 de maio de 2009 e abordou os seguintes temas: (I) a representação social do TI - mitos e verdades; (II) as implicações do TI no desenvolvimento biopsicossocial da criança e do adolescente; (III) a organização e as condições do trabalho encontradas no ramo de joias e folheados no município de Limeira, evidenciando o trabalho como insalubre/perigoso/ penoso e inadequado a crianças e adolescentes menores de 18 anos; (IV) distúrbios osteomusculares decorrentes das atividades de trabalho e suas repercussões na saúde das crianças e dos adolescentes; (V) Rede de Serviços de Limeira e o trabalho desenvolvido pela Cometil; (VI) Seminários especiais com exposições realizadas pelo MPT referentes à formulação e à importância do TAC; legislação vigente sobre TI e TA apresentada pelo MTE e; (VII) Palestra e atividade prática coordenada por uma docente da EE/USP.

\section{E13 - II audiência pública}

Foi realizada a II Audiência Pública no dia 16 de junho de 2009 para tornar público, pactuar e garantir o desenvolvimento das ações contidas nos projetos territoriais elaborados pelos funcionários públicos. $\mathrm{O}$ evento serviu para pactuar com o poder público a participação dos servidores capacitados, das diversas secretarias municipais, nos espaços de discussão para desenvolver e executar ações promotoras de saúde por microáreas do território.

\section{E14 - Constituição dos grupos territoriais}

Como resultado do curso de formação de multiplicadores e por meio da pactuação efetuada na II Audiência Pública, todos os cinco territórios constituíram comissões locais, nomeadas posteriormente de Grupos Territoriais de Erradicação do Trabalho Infantil (GTETI).

Esses grupos são compostos por servidores que atuam nos equipamentos públicos dos setores da Educação (municipal e estadual), da Secretaria $\mathrm{Mu}-$ nicipal de Saúde e do Ceprosom ${ }^{11}$ e, em alguns territórios, participam também outros atores sociais estratégicos como, por exemplo, associação de moradores. Os profissionais que trabalham nos equipamentos do território organizam e coordenam o espaço, tendo como suporte técnico e político a Cometil,por meio de seus facilitadores. Os membros da comissão vêm atuando em equipamento no território e acompanham as reuniões, fazendo o elo entre o território e a comissão.

Desde sua instituição, os grupos se reúnem mensalmente com os seguintes objetivos:

- discutir o cumprimento do TAC, enfatizando as condições dos equipamentos públicos localizados no território para realizá-lo e, quando necessário, cobrando o poder público por melhorias estruturais e/ou de outras naturezas;

- planejar e executar ações que contribuam para a prática intersetorial;

- organizar atividades e/ou eventos de mobilização da população para sensibilização e enfrentamento do TI e proteção do TA no território;

- proporcionar a continuidade da capacitação de multiplicadores para ETI entre servidores públicos, lideranças de associações de moradores, pastorais sociais, dentre outros, e refletir sobre as dificuldades identificadas nas práticas cotidianas do território;

- discutir casos.

\footnotetext{
${ }^{10} \mathrm{~A}$ ferramenta Showed pode ser sistematizada da seguinte forma: reconhecimento do problema (what do we see?); dimensões do problema naquela comunidade (what's really happening?); troca de informações sobre as diferentes experiências (how does her story relate to our lives?); questionamento das causas relacionadas ao problema, nas dimensões individual, familiar e social (why has she become an alcoholic?); quais as alternativas de fortalecimento (how we can become empowered?); perspectivação das ações necessárias para a mudança (what can we do?).

${ }^{11}$ Centro de Promoção Social Municipal - Autarquia que desenvolve as Políticas Públicas de Assistência Social.
} 
Dessa forma, garantiu-se um espaço de articulação entre os atores sociais que representam diferentes setores nos territórios, bem como um espaço de reflexões das práticas implementadas. Este processo conferiu aos técnicos dos três setores maior capacidade de dialogar e, quando necessário, de pressionar os gestores no sentido de garantir o funcionamento das políticas públicas voltadas à ETI.

\section{E15 - Criação do Programa de Saúde do Trabalhador}

Outro importante avanço, oriundo do TAC, foi a criação do Programa de Saúde do Trabalhador (PST) em Limeira. O PST ficou encarregado de desenvolver ações de vigilância em saúde do trabalhador seguindo as diretrizes da Portaria no 3.120/98 do Ministério da Saúde (BRASIL, 1998) no sentido de erradicar o trabalho de crianças e adolescentes.

O TAC também previu a criação de um sistema de identificação de casos de TI e TA que operaria por meio do preenchimento de uma ficha investigativa da situação de trabalho, a qual seria aplicada em todo atendimento realizado na rede de saúde para pacientes com idade inferior a 18 anos completos. As fichas seriam encaminhadas ao PST e este, por sua vez, deveria construir um banco de dados. O sistema de fichas de identificação operou apenas no ano de 2010, tendo como resultado o preenchimento de mais de 2 mil fichas, das quais 214 oriundas dos PSF e 168 preenchidas nas UBS indicavam suspeita de situação de trabalho. Os casos foram encaminhados ao Ceprosom, que teve a atribuição de avaliar caso a caso para inserir ou não no benefício do Peti e tomar outras providências.

As ações definidas contemplavam os anseios dos participantes da Cometil, no entanto, segundo os depoimentos colhidos e as práticas observadas pelos pesquisadores, o Pst ainda não desenvolve plenamente essas ações.

\section{Análise da trajetória da Cometil}

Ficou evidenciado no material coletado que o início das ações foi marcado por barreiras políticas e culturais manifestadas pela resistência de alguns setores da sociedade, principalmente pelo setor produtivo de joias e bijuterias e por algumas instâncias do poder público local que se mostravam coniventes à realidade da exploração do trabalho de criança e adolescente. No evento E4, tornou-se evidente que as primeiras barreiras a serem transpostas seriam aquelas de ordem política e cultural, evidenciadas nos discursos e na postura de gestores.
O discurso dos gestores municipais apresentados no E4 foram reveladores da posição política e ideológica sobre a questão e ilustraram os dissensos que existiam no processo de formação da referida comissão.

O Ceprosom, por sua vez, ao apresentar, no evento de 2007 (E4), o programa Jovens Brilhantes, que tinha como meta treinar jovens para a execução domiciliar de etapas do fluxo de produção de joias e bijuterias, mostrava inequívoco comprometimento das políticas públicas com a prática empresarial questionada pela pesquisa de Ferreira (1995). Dessa forma, o poder público institucionalizou o TA em uma atividade de risco, mostrando o despreparo, o descaso e a conivência com a situação de crianças e adolescentes em situação de trabalho.

Esse programa, bem como a postura apresentada pelos gestores no mesmo evento, e também na reunião realizada na Câmara Municipal de Limeira (E5), refletiram uma representação social sobre a infância identificada no estudo iconográfico realizado por Ariès (1981), no qual descreve a ideologia da burguesia no século XIX cuja principal característica era o direcionamento dos filhos de operários ao trabalho e os filhos da burguesia ao estudo. A despeito dos avanços iniciais, o desafio que se coloca é a desconstrução de dois séculos de ideologia que favorece a incorporação precoce de crianças e jovens nos processos produtivos.

Por meio de ações engendradas no âmbito da rede formada pela Cometil, foi delineado um processo de transformação cultural.

Os eventos organizados cronologicamente evidenciam a instituição de práticas intersetoriais que envolveram processo constante de negociação. Elas foram gestadas na Cometil, em forma de governança em rede, que emergiram em consensos antes inexistentes, pontos de convergência entre diferentes olhares que foram essenciais para o desencadeamento de ações.

A Cometil valeu-se de uma estratégia que considera a compreensão ampliada sobre o problema como ponto de partida para o êxito de qualquer política pública. Essas ações podem ser compreendidas como ações de Promoção da Saúde que visaram ao desenvolvimento de habilidades dos profissionais dos três setores (educação, saúde e assistência social) e ao empoderamento de atores sociais da sociedade civil.

A assinatura do TAC (E10) foi um marco nessas ações, uma vez que comprometeu a Prefeitura Municipal de Limeira a organizar e executar ações que foram essenciais para os avanços no sentido da prevenção e da erradicação do trabalho infantil e proteção do trabalho do adolescente. 
Este estudo mostrou que as instâncias municipais responsáveis pelo desenvolvimento de políticas voltadas à ETI não vinham desempenhando seu papel no município estudado. No entanto, com a mobilização iniciada pela Cometil e o respaldo do MPT, do MTE e do Cerest, ocorreram diversas ações, como mostrado na linha do tempo, fato que ilustra a importância da articulação intersetorial e do respaldo de instituições federais em ações locais (municipais) nas quais existem conflitos de interesses.

O curso de multiplicadores (E12), viabilizado pelo TAC, desempenhou papel estratégico, uma vez que disparou um processo de Educação Permanente em Saúde por meio da formação dos grupos territoriais (E14). A estratégia pedagógica de Paulo Freire usada no curso mostrou-se adequada para fomentar novas práticas sociais, tanto que fomentou a criação dos grupos que, desde então, continuam operando como um espaço para refletir as práticas. $\mathrm{Na}$ saúde, a maior aplicação do legado freiriano está relacionada aos processos de empoderamento e/ou desenvolvimento de habilidades, uma vez que, para o autor, o "verdadeiro conhecimento" está relacionado à interação entre a reflexão e a ação, ou seja, refletir sobre determinada prática, converter essa reflexão em novas ações e refletir sobre essas novas ações em um processo cíclico também denominado como práxis. O processo desencadeado pela práxis é capaz de produzir transformações sociais (FREIRE, 1998).

A ferramenta Showed (WALLERSTEIN; BERNSTEIN, 1998), utilizada no curso, proporcionou uma reflexão crítica acerca de uma questão entendida como problema para a tomada de decisão e mostrou como atuar na transformação da realidade social observada. Os servidores dos setores educação, saúde e assistência social, que no início das articulações intersetoriais naturalizavam o problema do TI e lhe atribuíam um caráter protetor e formador para crianças e adolescentes das classes sociais menos abastadas, assumiram outra posição e adotaram um olhar crítico a partir das diversas ações desencadeadas a partir do curso e das estratégias de formação de multiplicadores (E12).

Os GTETIs criados confirmam que a estratégia de territorializar as discussões realizadas na Cometil viabilizou reflexões e ações mais pertinentes, fundamentadas pela prática de cada profissional em cada setor, além de aproximar-se da demanda real que se apresenta de modo distinto em cada território. Segundo indicado em algumas atas e discussões acompanhadas por alguns dos autores deste artigo, essa estratégia foi assertiva, uma vez que potencializou as ações de cada setor e possibilitou alcançar de forma mais direta e com maior eficácia a população nos seus locais de moradia.

Outra evidência observada foi a organização de ações de sensibilização que alcançaram a população de cada um desses territórios. Com autonomia, cada grupo desenvolveu, ao longo dos anos de 2009, 2010 e 2011, estratégias de sensibilização com enfoques distintos para alcançar públicos distintos.

A importância desses grupos reside no fato de que os territórios são espaços de relações, trocas, construção e desconstrução de vínculos cotidianos, de disputas, contradições e conflitos, de expectativas e sonhos, enfim, são os espaços nos quais a vida dos sujeitos se desenrola. Por essa razão, deve ser também o terreno das políticas públicas, onde se concretizam as manifestações da questão social e se formatam os tensionamentos e as possibilidades para imprimir um novo curso nessa trajetória.

Nesse sentido, a Cometil vem conseguindo transpor barreiras e dá continuidade ao processo de "transformação cultural" enfrentando o desafio que é desconstruir a "ideologia do trabalho".

A partir dos achados desta pesquisa, os autores sintetizaram o Quadro 2, que reúne informações segundo categorias e avalia alguns aspectos dos avanços obtidos por meio da formação e da consolidação da Cometil.

Do ponto de vista da produção de conhecimento e desenvolvimento de ações intervencionistas, faz-se necessário refletir sobre as abordagens e as ferramentas possíveis e capazes de alcançar as mudanças desejadas. O método de pesquisa e intervenção utilizado - a pesquisa-ação - valorizou e potencializou o protagonismo dos atores sociais em busca da transformação da realidade, especialmente dos trabalhadores do setor público e parte dos representantes sindicais. Contudo, encontrou limite no sentido de não apresentar ferramenta teórica que pudesse colocar todos os atores diante da realidade, de modo a identificar e enfrentar as contradições deste sistema de atividade. Em outras palavras, participar sem incluir no processo o estudo das contradições e da evolução histórica do setor parece ter contribuído para deixar para segundo plano o enfrentamento da realidade social a ser transformada.

A metodologia do "Laboratório de Mudanças" (LM) proposta por Engeström (2007) parece ser mais adequada para estudos e intervenções que visam a alterações no sistema produtivo por meio da implicação e envolvimento dos atores sociais, de modo a torná-lo sustentável, tanto do ponto de vista das relações humanas, quanto do meio ambiente (ENGESTRÖM, 2007; PEREIRA-QUEROL; JACKSON; CASSANDRE, 2011). 
Quadro 2 Avaliação segundo dimensões observadas no estudo "A construção de políticas públicas em rede intersetorial para a erradicação do trabalho infantil em Limeira-SP”*, antes e depois da formação e consolidação da Cometil ${ }^{* *}$

\begin{tabular}{|c|c|c|c|}
\hline Dimensões avaliadas & Antes da Cometil & Depois da Cometil & Norteadores para continuidade \\
\hline Conceito de trabalho infantil & $\begin{array}{l}\text { Visão acrítica do trabalho } \\
\text { infantil }\end{array}$ & $\begin{array}{l}\text { Visão crítica em parcelas cres- } \\
\text { centes dos atores sociais }\end{array}$ & $\begin{array}{l}\text { Aprofundar e dar seguimen- } \\
\text { to às mudanças culturais }\end{array}$ \\
\hline $\begin{array}{l}\text { Capacidade técnica dos } \\
\text { profissionais dos setores Edu- } \\
\text { cação, Saúde e Assistência } \\
\text { Social para a ETI'" (promoção } \\
\text { da saúde) }\end{array}$ & $\begin{array}{l}\text { Baixa capacidade técnica; } \\
\text { Poucos técnicos atuando; }\end{array}$ & $\begin{array}{l}\text { Aprimoramento técnico para } \\
\text { enfrentamento do problema; } \\
\text { Número crescente de técnicos } \\
\text { atuando }\end{array}$ & \multirow{2}{*}{$\begin{array}{l}\text { Dar continuidade às ações } \\
\text { implementadas }\end{array}$} \\
\hline $\begin{array}{l}\text { Empoderamento dos profis- } \\
\text { sionais envolvidos e da } \\
\text { população como um todo } \\
\text { (promoção da saúde) }\end{array}$ & $\begin{array}{l}\text { Pouca ou nenhuma governabi- } \\
\text { lidade sobre o problema }\end{array}$ & $\begin{array}{l}\text { Ampliação da governabilidade } \\
\text { sobre o problema (Termo de } \\
\text { Ajustamento de Conduta e inter- } \\
\text { setorialidade) }\end{array}$ & \\
\hline Ações de Vigilância em Saúde & $\begin{array}{l}\text { Não existiam ações de vigilân- } \\
\text { cia em saúde }\end{array}$ & $\begin{array}{l}\text { Criação do Programa de Saúde } \\
\text { Trabalhador; } \\
\text { Levantamento da situação de tra- } \\
\text { balho infantil entre os usuários } \\
\text { do SUS (2010); } \\
\text { Registros de acidente de tra- } \\
\text { balho no Sinan e criação do Sivat }\end{array}$ & $\begin{array}{l}\text { Avançar nas formas de } \\
\text { abordagem; } \\
\text { Envolvimento dos trabal- } \\
\text { hadores e empresários; } \\
\text { Intervenção no fluxo do Ar- } \\
\text { ranjo Produtivo Local; } \\
\text { Aprimorar fluxo de infor- } \\
\text { mações entre PST e Cometil }\end{array}$ \\
\hline $\begin{array}{l}\text { Governança em rede (con- } \\
\text { struindo a intersetorialidade) }\end{array}$ & Não existia rede constituída & $\begin{array}{l}\text { A Cometil e os GTETIs viabili- } \\
\text { zam o processo de governança } \\
\text { em rede; } \\
\text { fluxograma intersetorial para } \\
\text { encaminhamentos de casos } \\
\text { ao Centro de Promoção Social } \\
\text { (Ceprosom). }\end{array}$ & $\begin{array}{l}\text { Dar prosseguimento e asseg- } \\
\text { urar a participação de atores } \\
\text { sociais para a transformação } \\
\text { do quadro atual }\end{array}$ \\
\hline
\end{tabular}

"Lacôrte (2012).

"Comissão Municipal de Erradicação do Trabalho Infantil de Limeira

* Erradicação do Trabalho Infantil

-m Grupos Territoriais de Erradicação do Trabalho Infantil

\section{Conclusão}

O estudo revelou a necessidade de múltiplas estratégias para enfrentar o problema complexo que envolve o trabalho infantil e adolescente, algumas dessas iniciadas pelo trabalho da Cometil. No entanto, são imprescindíveis outras iniciativas de políticas públicas, pesquisas e intervenções para comprometer e mobilizar o empresariado e os trabalhadores do setor no sentido de equacionar o problema das terceirizações que dispersam parcelas do fluxo produtivo para o trabalho familiar.
A experiência da Cometil indica, por meio da formação e atuação dos GTETI, a potencialidade da estratégia da governança em rede aliada às práticas de Educação Permanente em Saúde, as quais ampliaram a capacidade dos técnicos atuarem sobre os determinantes de saúde. A estratégia se mostrou funcional em Limeira e a complexidade das questões enfrentadas sugere que também possa funcionar em outras localidades que apresentem problemas similares.

Os avanços observados se referem à construção de um olhar crítico por parte dos servidores muni- 
cipais em relação ao problema do TI e do TA desprotegido, no entanto, é necessário avançar no envolvimento de trabalhadores e empresários do setor produtivo de joias para nele promover alterações.

A realidade estudada requer da Cometil e dos seus parceiros a proposição e a implantação de políticas públicas que visem também à geração de emprego e renda para melhoria da situação socioeconômica das famílias de modo que elas tenham condições financeiras para recusar propostas de trabalho perigosas como as ofertadas pelo fluxo produtivo em questão.

O caso estudado evidencia também que persiste no país, por ação ou omissão do Estado, famílias que, na busca por sobrevivência ou incremento no rendimento familiar imediato, entram em um ciclo vicioso que resulta na interdição da infância e no comprometimento do futuro de suas crianças e jovens que, pelo trabalho, podem ser condenados a uma limitação no desenvolvimento de suas capacidades. Consequentemente, essas crianças e jovens poderão se tornar adultos marginalizados, uma vez que não puderam se preparar devidamente para responder às exigências de qualificação do mercado de trabalho.

Na situação específica de Limeira, a mudança nos determinantes sociais situados no fluxo produtivo demanda, por parte do empresariado, o reconhecimento de que responsabilidade social implica no controle sobre a organização do trabalho e do seu fluxo produtivo. A organização do APL de joias e bijuterias de Limeira, caracterizada pelo processo de terceirização predatória, representa uma barreira para a sustentabilidade e a responsabilidade social. Se não é possível à empresa responsabilizar-se pe- las consequências adversas do processo de terceirização, como afirmam os representantes do setor, a postura correta seria, então, não contratar terceiros e reabsorver os trabalhadores do setor. Ao contrario do alegado, o fato concreto é que as empresas formais e informais estão intrinsecamente ligadas: a produção formal depende das etapas informais para garantir o baixo custo produtivo.

Nesse sentido, a não adesão dos representantes patronais e dos trabalhadores do setor produtivo tem se mostrado a maior dificuldade para as ações intersetoriais promovidas pela Cometil e inviabiliza uma intervenção focada nos determinantes, como preconizam os pressupostos da vigilância em saúde do trabalhador.

Para transpor essa barreira, são necessárias novas intervenções de políticas públicas que incidam sobre o fluxo produtivo e o induza a mudanças, por exemplo, por meio de financiamentos e incentivos que incluam como pré-requisitos a eliminação das terceirizações predatórias e o equacionamento dos problemas ambientais. Para essa finalidade, a metodologia do Laboratório de Mudanças será testada na continuidade das intervenções junto ao setor, uma vez que sua aplicação parece mais adequada ao enfrentamento dos desafios que vêm sendo percebidos justamente por preconizar um processo em que os atores sociais envolvidos criam coletivamente um novo objeto e motivo para suas atividades, assim como novas ferramentas e formas de organização social para resolver contradições que colocam a atividade em crise (ENGESTRÖM, 1999; PEREIRA-QUEROL; JACKSON; CASSANDRE, 2011).

\section{Contribuições de autoria}

Todos os autores tiveram contribuição substancial no levantamento e na análise dos dados e no processo de elaboração e revisão do manuscrito.

\section{Referências}

ALVES, G. O novo (e precário) mundo do trabalho: reestruturação produtiva e a crise do sindicalismo. São Paulo: Boitempo, 2000.

ANTUNES, R. Dimensão da precarização estrutural. In: DRUCK, G.; FRANCO, T. A perda da razão social do trabalho. São Paulo: Boitempo, 2007. p. 13-22

ASMUS, C. I. R. F. et al. Atenção integral à saúde de adolescentes em situação de trabalho: lições aprendidas. Ciência \& Saúde Coletiva, Rio de Janeiro, v. 10, n. 4, p. 953-960, 2005.

ARIÈS, P. História social da criança e da família. Rio de Janeiro: Guanabara, 1981.
BRASIL. Lei no 8.069, de 13 de julho de 1990.

Dispõe sobre o Estatuto da Criança e do Adolescente. Disponível em: <http://www.planalto.gov.br/ccivil_03/ leis/L8069.htm>. Acesso em: 4 abr. 2010.

. Ministério da Saúde. Portaria no 777, de 28 de abril de 2004. Dispõe sobre os procedimentos técnicos para a notificação compulsória de agravos à saúde do trabalhador em rede de serviços sentinela específica, no SUS. Disponível em: <http://dtr2001.saude.gov.br/ sas/PORTARIAS/Port2004/GM/GM-777.htm > . Acesso em: 13 maio 2010. 
BRASIL. Portaria no 3.120, de 1 julho de 1998. Instrução normativa sobre ações de vigilância em saúde do trabalhador no SUS. Diário Oficial [da] República Federativa do Brasil, Brasília, DF, 2 jul. 1998. Seção I, p. 36. Disponível em: < http://www. cerest.rn.gov.br/contentproducao/aplicacao/sesap_ cerest/legislacao/gerados/portaria\%203.120.pdf $>$. Acesso em: 25 out. 2013.

Secretaria de Atenção à Saúde. Departamento de Ações Programáticas Estratégicas. Trabalho infantil: diretrizes para atenção integral à saúde de crianças e adolescentes economicamente ativos. Brasília, DF: Ministério da Saúde, 2005a.

. Secretaria de Atenção Integral à Saúde. Área de Saúde do Adolescente e do Jovem. Marco legal: saúde, um direito de adolescentes. Brasília: Ministério da Saúde, 2007.

Secretaria de Políticas de Saúde. Projeto Promoção da Saúde. As cartas da promoção da saúde. Brasília, DF: Ministério da Saúde, 2002. Disponível em: <http://bvsms.saude.gov.br/bvs/publicacoes/ cartas_promocao.pdf>. Acesso em: 23 out. 2013.

Ministério do Desenvolvimento Social e Combate à Fome. Portaria no 431, de 03 de dezembro de 2008. Disponível em: < http://www. mds.gov.br/assistenciasocial/legislacao-2011/ portarias/2008/Portaria\%20no\%20431-\%20de\%20 03\%20de\%20Dezembro\%20de\%202008.pdf/ view?searchterm = peti $>$. Acesso em: 4 abr. 2010.

. Portaria no 458, de 04 de outubro de 2001. Disponível em: <http://www.mds.gov.br/ sobreoministerio/legislacao/assistenciasocial/ portarias/2001/Portaria\%20no\%20458-\%20de\%20 04\%20de\%20outubro\%20de\%202001.pdf>. Acesso em: 4 maio 2010.

. Portaria no 555, de 11 de novembro de 2005b. Estabelece normas e procedimentos para a gestão de benefícios do Programa Bolsa Família, criado pela Lei no 10.836, de 9 de janeiro de 2004. Disponível em: <http://www.mds.gov.br/bolsafamilia/legislacao-1/ portarias/2005/Portaria\%20GM\%20MDS\%20555\%20 11-11-05.pdf>. Acesso em: 4 mar. 2010.

. Portaria no 666, de 28 de dezembro de 2005c. Disciplina a integração entre o Programa Bolsa Família e o Programa de Erradicação do Trabalho Infantil. Diário Oficial [da] República Federativa do Brasil, Seção 1, n. 251, 30 dez. 2005. Disponível em: <http:/www.mds.gov.br/sobreoministerio/legislacao/ bolsafamilia/portarias/2005/ Portaria\%20GM\%20 MDS\%20666\%2028-12-05.pdf/view>. Acesso em: 4 abr. 2010 .

. Ministério do Trabalho e Emprego. Plano Nacional de Prevenção e Erradicação do Trabalho Infantil e Proteção ao Trabalhador Adolescente. Brasília: MTE, 2004. 82 p.

. Ministério Público do Trabalho. Procuradoria Regional do Trabalho 15a Região. Termo de
Compromisso de Ajustamento de Conduta 5537/2009, $21 \mathrm{p}$.

CAMPOS, H. R.; ALVERGA, A. R. Trabalho infantil e ideologia: contribuição ao estudo da crença indiscriminada na dignidade do trabalho. Estudos de Psicologia, Natal, v. 6. n. 2, p. 227-233, 2001.

CARVALHO, I. M. M. de. Algumas lições do Programa de Erradicação do Trabalho Infantil. Perspectivas, São Paulo, v. 18, n. 4, p. 50-61, dez. 2004.

CASTEL, R. A nova questão social. In: . As metamorfoses da questão social: uma crônica do salário. Rio de Janeiro: Vozes, 1998. p. 495-591.

CECCIM, R. B. Educação permanente em saúde: descentralização e disseminação de capacidade pedagógica na saúde. Ciência \& Saúde Coletiva, Rio de Janeiro, v. 10, n. 4, p. 975-986, 2004.

. Educação permanente em saúde: desafio ambicioso e necessário. Interface - Comunicação, Saúde, Educação, Botucatu, v. 9, n. 16, p. 161-177, set. 2004/fev. 2005.

CENTRO INTEGRADO DE ESTUDOS E PROGRAMAS DE DESENVOLVIMENTO SOCIAL (CIEDS). Balanço social anual 2006. 2006. Disponível em: < http://www. cieds.org.br/relatorios/Balan\%C3\%A7o_social_2006. pdf>. Acesso em: 21 nov. 2011.

\section{COMISSÃO MUNICIPAL DE ERRADICAÇÃO DO}

TRABALHO INFANTIL. Relatório analítico. 1a Audiência pública sobre o trabalho infantil. Limeira, SP, julho 2007a. 41 p. Mimeografado.

. Relatório analítico. 1올 Seminário Municipal para erradicação do trabalho infantil: diagnóstico e alternativas. Limeira, SP, set. 2007b. 23 p. Mimeografado.

. Relatório de sistematização das propostas. Oficina de integração interinstitucional das ações públicas para a erradicação do trabalho infantil no Município de Limeira. Limeira, SP, out. 2007c. 21 p. Mimeografado.

COULON, A. L'École de Chicago. Paris: Presses Univessitaires de France, 1992.

ENGESTRÖM, Y. Activity theory and individual and social transformation. In: ENGESTRÖM, Y.; MIETTINEN, R.; PUNAMÄKI, R. L. (Org.). Perspectives on activity theory. Cambridge: Cambridge University Press, 1999. p. 19-38.

. Putting Vygotsky to work: the change laboratory as an application of double stimulation. In: DANIELS, H.; COLE, M.; WERTSCH, J. V. (Org.). The Cambridge Companion to Vygotsky. Cambridge: Cambridge University Press, 2007. p. 363-382.

FERREIRA, M. A. F. Trabalho infantil e produção acadêmica nos anos 90: tópicos para reflexão. Estudos de Psicologia, Natal, v. 2, n. 6, p. 213-225, 2001.

FERREIRA. M. A. L. Estudo dos riscos à saúde do trabalhador e ao meio ambiente na produção de 
joias e bijuterias de Limeira. 1995. 185 f. Dissertação (Mestrado)-Engenharia de Produção - Unimep, Piracicaba, 1995.

FREIRE, P. Pedagogia do oprimido. São Paulo: Paz e Terra, 1998.

INSTITUTO BRASILEIRO DE GEOGRAFIA E ESTATÍSTICAS. PNAD 2001: Pesquisa nacional de amostra por domicílio - Trabalho infantil. Brasília, DF: IBGE, 2001.

KAMP, A.; NIELSEN, K. T. Regulação em rede do ambiente de trabalho. Revista Brasileira de Saúde Ocupacional, São Paulo, v. 34, n. 119, p. 15-27, 2009.

LACORTE, L. E. C. A construção de políticas públicas em rede intersetorial para a erradicação do trabalho infantil em Limeira - SP, 2012. 160 f. Dissertação (Mestrado em Saúde Ambiental)-Faculdade de Saúde Pública, Universidade de São Paulo, São Paulo, 2012.

LIMEIRA (Município). Câmara de Vereadores de Limeira. Registro audiovisual. 1오eminário Municipal para Erradicação do Trabalho Infantil: diagnóstico e alternativas, Limeira, 24 de agosto de 2007. Limeira, SP: Câmara de Vereadores, 2007a.

. Câmara de Vereadores de Limeira. Registro audiovisual do evento. 1ํ Audiência Pública: 12 de junho de 2007. 2007b.

MAENO, M. et al. Lesões por Esforços Repetitivos (LER) Distúrbios Osteomusculares Relacionados ao Trabalho (DORT). Ministério da Saúde, 2001. Disponível em: <www.saude.gov.br/publicações > . Acesso em: 10 nov. 2011.

MINAYO-GOMEZ, C.; MEIRELLES, Z. V. Crianças e adolescentes trabalhadores: um compromisso para a saúde coletiva. Cadernos de Saúde Pública, Rio de Janeiro, v. 13, Supl. 2, p. 135-140, 1997.

NOBRE, L. C. C. Trabalho de crianças e adolescentes os desafios da intersetorialidade e o papel do Sistema Único de Saúde. Ciência e Saúde Coletiva, Rio de Janeiro, v. 8, n. 4, p. 963-971, 2003.

NOVOTNY, L. E. B. W. et al. Boas Práticas nas Ações Intersetoriais em Saúde: uma Iniciativa para a Prevenção e Erradicação do Trabalho Infantil no Pólo de Produção de Joias e Bijuterias de Limeira-SP. In: BARKER, S. L. (Org.). Boas práticas do setor saúde para a erradicação do trabalho infantil. Brasília: Organização Internacional do Trabalho, 2009. p. 39-45.

ORGANIZAÇÃO INTERNACIONAL DO TRABALHO. Combate ao trabalho infantil, 2011. Disponível em: <http://www.oit.org.br/content/combate-ao-trabalhoinfantil-0>. Acesso em: 13 nov. 2011.

ORGANIZAÇÃO MUNDIAL DO TRABALHO.

Convenção 182: Convenção sobre a proibição e ação imediata para erradicação das piores formas do trabalho infantil. 1999. Disponível em: <http://www. oit.org.br/sites/all/ipec/normas/conv182.php >. Acesso em: 9 maio 2011.

PEREIRA-QUEROL, M. A.; JACKSON FILHO, J. M.; CASSANDRE, M. P. Change Laboratory: uma proposta metodológica para pesquisa e desenvolvimento da Aprendizagem Organizacional. Administração: Ensino e Pesquisa, Rio de Janeiro, v. 12, n. 4, p. 609-640, 2011.

QUIROGA, A. A produção de joias e bijuterias em Limeira, SP, um problema silencioso. Jornal da Cultura, São Paulo, 11 abr. 2009.

ROCHA, M. L.; AGUIAR, K. F. Pesquisa-intervenção e a produção de novas análises. Psicologia Ciência e Profissão, Brasília, v. 23, n. 4, p. 64-73, 2003.

SCHWARTZMAN, S. Trabalho infantil no Brasil. Brasília: OIT, 2001.

THIOLLENT, M. Metodologia da pesquisa-ação. São Paulo: Cortez, 2000.

THOMPSON, E. P. A formação da classe operária inglesa II: a maldição de Adão. Rio de Janeiro: Paz e Terra, 1987.

TONOCCHI, M. Produção de jóias em Limeira emprega 6 mil crianças e jovens. Jornal O Estado de São Paulo, São Paulo, 12 dez. 2006, p. A14. Disponível em: <http://aprendiz.uol.com.br/content/crunislupr. mmp > . Acesso em: 30 out. 2013.

TRABALHO infantil: uso de solda faz 11 menores perderem impressão digital. Gazeta de Limeira, Limeira, p. 1-2, 25 de ago. 2007. Disponível em: <http://www.gazetadelimeira.com.br/site/index >. Acesso em: 30 set. 2009

UNITED NATIONS. Declaration of the Rights of the Child, 2000. Proclaimed by General Assembly resolution 1386-XIV of 20 November, 1959. Disponível em: <http://www.unhchr.ch/html/menu3/b/25.htm>. Acesso em: 12 jan. 2009.

VILANI, J. A. S. A questão do trabalho infantil: mitos e verdades. Inclusão Social, Brasília, v. 2, n. 1, p. 83-92, out. 2006/mar. 2007.

VILELA, R. A. G.; FERREIRA, M. A. L. Nem tudo brilha na produção de joias de Limeira - SP. Produção, São Paulo, v. 18, n. 1, p. 183-194, jan./abr. 2008.

WALLERSTEIN, N.; BERNSTEIN, E. Empowerment education: Freire's ideas adapted to health education. Health Education Quarterly, New York, v. 15. n. 4, p. 379-394, 1988.

YIN, R. K. Estudo de caso: planejamento e métodos. 2. ed. Porto Alegre: Bookman, 2002. 